\section{Pemanfaatan Aplikasi Drone Emprit Academic dalam Menganalisis Opini Publik di Media Sosial}

\author{
Bambang Arianto \\ Peneliti Center for Forensic Accounting \\ and Social Media Studies
}

Korespondensi penulis: ariantobambang2020@gmail.com

\begin{abstract}
Abstrak
Tujuan penelitian ini adalah untuk mengetahui perilaku warganet di media sosial dalam setiap isu yang berkembang. Hal itu disebabkan, media sosial bisa dipergunakan untuk melacak dengan mudah informasi dan opini masyarakat yang lagi trending. Apalagi, saat ini media sosial telah menjadi saluran untuk mencari informasi, interaksi, partisipasi dan desentralisasi di semua lini kehidupan masyarakat. Penelitian ini menggunakan pendekatan kualitatif untuk melakukan analisis data hasil percakapan media sosial dengan bantuan aplikasi Drone Emprit Academic (DEA) Universitas Islam Indonesia. Aplikasi ini merupakan kumpulan data besar (big data) dari seluruh percakapan warganet di media sosial dalam konteks internasional. Penelitian ini mengungkapkan bahwa aplikasi Drone Emprit Academic menjadi salah satu aplikasi untuk mengetahui percakapan warganet di media sosial. Penelitian ini juga menyatakan bahwa aplikasi Drone Emprit Academic (DEA) bisa digunakan untuk menganalisis opini publik yang berkembang secara kekinian.
\end{abstract}

Kata Kunci: Drone Emprit Academic, Warganet, Media Sosial

\section{Using the Emprit Academic Drone Application in Analyzing Public Opinion on Social Media}

\begin{abstract}
The purpose of this study was to determine the behavior of netizens on social media in every developing issue. This is because social media can be used to easily track trending information and public opinion. Moreover, nowadays social media has become a channel for seeking information, interaction, participation and decentralization in all walks of life. This study uses a qualitative approach to analyze data from social media conversations with the help of the Drone Emprit Academic (DEA) application of the Islamic University of Indonesia. This application is a collection of big data (big data) from all warganet conversations on social media in an international context. This research reveals that the Drone Emprit Academic application is one of the applications to find out netizen conversations on social media. This study also states that the Drone Emprit Academic (DEA) application can be used to analyze public opinion that is currently developing.
\end{abstract}

Keywords: Emprit Academic Drone, Warganet, Social Media 


\section{A. PENDAHULUAN}

Perkembangan teknologi informasi membuat kehidupan saat ini lebih mengedepankan gaya hidup digital. Hal itu bisa dilacak dari kehidupan keseharian yang tidak lepas dari teknologi informasi. Dalam konteks ini salah satu varian dari teknologi informasi yang semakin meluas penggunaannya oleh publik adalah media sosial. Dengan kata lain, media sosial telah menjadi suatu kebutuhan bagi publik saat ini. Media sosial secara dramatis telah mengubah lanskap sosial dan cara kita memahami perihal partisipasi (Lewis, S., \& Rosen, J. (2010).

Dengan konteks ini media sosial diartikan sebagai sekelompok aplikasi berbasis internet yang dibangun atas dasar ideologi dan teknologi web 2.0 sehingga memungkinkan penciptaan dan pertukaran user generated content (Kaplan \& Haenlein, 2010). Hal itu tanpa alasan, sebab saat ini mayoritas penduduk di Indonesia memiliki media sosial, terutama para generasi milenial dan generasi Z. Ada beberapa alasan penggunaan media sosial yang semakin meluas, diantaranya; sebagai sarana untuk mencari informasi, saluran interaksi, partisipasi dan terakhir desentralisasi.

Untuk yang pertama sebagai saluran informasi, disebabkan publik lebih cepat mencari informasi terkini dari media sosial daripada harus mencari dari media mainstream yang berbentuk hardcopy. Selain itu, untuk saluran interaksi telah banyak bukti bahwa media sosial telah membuat ruang publik baru untuk berinteraksi. Banyak warganet yang memanfaatkan media sosial untuk bersosialisasi hingga mencari pertemanan baru. Selanjutnya, terkait saluran partisipasi, media sosial seringkali digunakan untuk berpartisipasi aktif dalam berbagai hal, baik itu dalam berbagai menyingkapi maupun mengkritisi kebijakan publik. Lebih lanjut, media sosial bisa menjadi sarana desentralisasi yakni sebagai sarana untuk mendekatkan diri antara pemerintah dan publik. Hal ini dikarenakan media sosial telah membentuk ruang baru tanpa sekat. Dengan begitu publik akan ikut berpartisipasi untuk menyampaikan berbagai aspirasinya melalui media sosial. Aspirasi ini dapat berupa otokritik, protes maupun masukan terhadap berbagai kebijakan publik yang tlelah dikeluarkan oleh pemerintah.

Meski demikian, dalam perkembanganya media sosial mengalami perubahan drastis hingga saat ini. Pada awalnya media sosial mulai dikenal sejak kehadiran Friendster yang kemudian tergantikan oleh kehadiran Facebook, Twitter dan Instagram hingga saat ini. Arus perkembangan digitalisasi yang cukup pesat membuat media sosial banyak mengalami perubahan dan pertambahan. Hingga saat ini tercatat kurang lebih 30 media sosial yang hadir di dunia. Meski demikian, media sosial ini terbagi dari dua kelompok, yakni privat dan publik. Sedangkan untuk media sosial yang terfavorit atau paling banyak digunakan menurut data Houte Suite yakni Whatsapp, Facebook, Youtube, Instagram dan Twitter (Fahmi, 2019).

Dalam sejarahnya, jejaring sosial atau dikenal dengan media sosial, berawal dari hadirnya Classmates.com pada tahun 1994 yang diciptakan oleh seorang lulusan teknik industri bernama Randy Conrads. Classmates.com pada 
awal pendirian ditujukan untuk membantu para anggotanya menemukan teman lama dan teman satu angkatan. Tetapi seiring berjalannya waktu, Mark Goldston, lebih memfokuskan Clasmates pada konten nostalgia seperti buku tahunan, trailer film musik dan foto. Kemudian ada SixDegrees.com yang merupakan situs web layanan jejaring sosial yang hadir pada tahun 1997 hingga 2001. Jejaring sosial ini memungkinkan pengguna dapat mengirim pesan dan memposting item papan buletin kepada beberapa orang baik pada tingkat pertama, kedua, dan ketiga, serta dapat melihat koneksi mereka ke pengguna lain di situs. SixDegrees merupakan situs jejaring sosial pertama dari bentuk umum yang kemudian digunakan secara luas saat ini.

Media sosial mengalami perkembangan yang cukup pesat ketika muncul Ryze.com pada tahun 2001 yang kala itu berfungsi memperbesar jejaring bisnis. Sedangkan pada tahun 2002, hadir Friendster sebagai media sosial anak muda pertama yang ditujukan sebagai saluran pencarian jodoh. Lebih lanjut, pada tahun 2003, muncul media sosial interaktif yaitu Flick $\mathrm{R}$ dan Myspace. Puncaknya pada tahun 2004 muncul platform Facebook yang merupakan jejaring sosial yang menitikberatkan pada tempat kerja, sekolah, perguruan tinggi atau pertemanan.

Selanjutnya, perkembangan media sosial diikuti oleh kehadiran Reddit yang didirikan oleh Steve Huffman, Aaron Swartz, dan Alexiz Ohanian, tahun 2005 di Amerika Serikat. Media sosial Reddit merupakan sebuah forum jejaring yang hampir menyerupai Kaskus atau juga Kompasiana. Akan tetapi, Reddit kemudian di akuisisi oleh Conde Nast Publications pada oktober 2006. Pada september 2011 Reddit dipisahkan dari Conde Nast yang kemudian menjadi anak perusahaan induk Conde Nast yaitu Advance Publications. Lebih lanjut ada media sosial Youtube yang memungkinkan pengguna menggunggah, menonton dan berbagi video. Youtube didirikan oleh tiga mantan karyawan PayPal pada Februari 2005.

Lebih lanjut, hadir media sosial Twitter sebuah jejaring sosial mikroblog yang memungkinkan pengguna mengirim pesan teks. Pada awalnya, Twitter hanya bisa mengirim 140 karakter dan sejak 7 November 2017 bertambah menjadi 280 karakter. Media sosial Twitter berdiri Maret 2006 oleh Jack Dorsey dan situs jejaring sosialnya diluncurkan pada bulan Juli. Kemudian pada tahun 2007 ada media sosial Tumblr yang merupakan platform mikroblog sehingga memungkinkan pengguna mengirimkan konten dalam bentuk blog pendek. Selanjutnya ada Whatsapp yang merupakan aplikasi pesan untuk smartphone dengan dasar menyerupai BlackBerry Messenger. Media sosial Whatsapp didirikan oleh Brian Acton dan Jan Koum pada tahun 2009.

Lebih lanjut, terdapat media sosial Instagram yang didirikan pada 6 oktober 2010 yang memfokuskan pada jejaring sosial untuk berbagi foto dan video. Instagram memungkinkan pengguna menggunggah foto yang bisa diedit dengan berbagai filter. Seiring perkembangan, media sosial memperbaruhi fitur seperti; menandai akun lain, lokasi, siaran langsung (live) dan swipe up. Sedangkan April 2012, Instagram di akuisisi oleh Facebook. 
Lebih lanjut, pada Maret 2010 oleh Ben Silberman hadir kembali media sosial Pinterest yang merupakan aplikasi virtual pin-board. Sehingga memungkinkan pengguna bisa mengunggah foto dalam semacam album ataupun folder.

Selanjutnya hadir media sosial LINE asal Jepang yang memungkinkan pengguna bisa berkomunikasi, membuat grup, menyimpan gambar dan video. LINE berdiri pada Juni 2011 dan mulanya hanya digunakan pada sistem IOS dan Android. Tepat tahun 2012 LINE dapat digunakan untuk perangkat Mac dan Windows. Terakhir ada media sosial Tiktok yang dikembangkan Bytedance di China. TikTok dikenal sebagai Douyin artinya video pendek yang diluncurkan pada September 2016 oleh Zhang Yiming. Tiktok merupakan layanan jejaring sosial di mana pengguna dapat berbagi video berdurasi pendek dengan menampilkan musik sebagai latar belakang yang bisa dimodifikasi.

Dengan pesatnya perkembangan media sosial dekade terakhir membuat perannya semakin menguat dalam nalar publik. Media sosial kemudian digunakan untuk berbagai saluran partisipasi termasuk untuk membaca opini publik yang tengah berkembang ditengah masyarakat. Apalagi, dalam konteks Indonesia, saat ini banyak isu-isu popular justru berasal dari media sosial. Sedangkan untuk konteks politik Indonesia, peran media sosial menjadi salah satu saluran terpenting dalam membangun citra dan opini publik. Akan tetapi, menurut beberapa studi tidak semua peran media sosial berpengaruh. Seperti di Belanda, media sosial tidak secara signifikan mempengaruhi perilaku memilih selama pemilihan lokal. Meski demikian, selama pemilihan nasional sejak tahun 2010, politisi yang telah melibatkan penggunaan media sosial yang lebih tinggi telah mendapat suara relatif lebih banyak dari sebagian besar partai politik (Effing, R., et.al, 2011).

Hal itu sangat berbeda dalam konteks politik Indonesia, yang mana media sosial memiliki andil yang besar dalam setiap kontestasi. Bahkan untuk keseharian, media sosial telah mampu memberikan kontribusi nyata dalam membangun opini publik dalam konteks Indonesia. Dikarenakan kehadiran media sosial telah membuka kesempatan tiap pihak yang terlibat untuk mengeksistensikan dirinya dengan lebih luas melalui status maupun komentar terkait persoalan terkini (Watie, E. D. S, 2016). Dengan kata lain, media sosial telah bermanifestasi menjadi opini publik melalui sentiment hingga tren yang terkini (McGregor, S. C, 2019).

Oleh sebab itu, tentu diperlukan alat untuk bisa menganalisis percakapan para warganet tersebut diperlukan aplikasi yang bisa mendeteksi secara detil. Berdasarkan identifikasi tersebut, penelitian ini akan mengelaborasi kembali peran aplikasi Drone Emprit Academic (DEA) Universitas Islam Indonesia dalam membaca tren yang berkembang di warganet secara kekinian. Penelitian ini akan menganalisis kata kunci Bank dan Muhammadiyah yang telah menjadi bahan perbincangan para warganet di media sosial. Lebih lanjut penelitian ini akan lebih menekankan pada percakapan warganet di media sosial Twitter.

Data besar yang disediakan oleh Drone Emprit Academic mampu menemukan fenomena sosial. Hasil 
penelitian ini menunjukan bahwa Drone Emprit Akademic adalah sistem data besar yang melakukan analisis jejaring sosial spesifik percakapan di Twitter semi-realtime dan detail. Formulir yang ditampilkan adalah dalam bentuk persentase tren, retweet hubungan, menyebutkan tren grafik, sebagian besar status retweet, tren percakapan. Dengan demikian, data-data ini bisa menjadikan rujukan untuk membaca berbagai dan fenomena sosial yang terjadi saat ini.

Dengan begitu, perbedaan penelitian ini sebelumnya terletak pada penggunaan aplikasi Drone Emprit Academic dalam menganalisa opini publik di media sosial. Dengan demikian, artikel ini mengajak pada pertanyaan, bagaimana pemanfaatan aplikasi Drone Emprit Academic dalam menganalisis opini publik di media sosial. Penelitian ini membatasi mengenai peran dan implikasi dari aplikasi Drone Emprit Academic dalam membaca opini publik di media sosial terkait kata kunci Bank dan Muhammdiyah.

\section{B. TEORI (Literature Review)}

\section{Media Sosial}

Pada saat ini mayoritas penduduk di dunia telah menggunakan media sosial dengan berbagai tujuan. Dalam konteks ini media sosial didefinisikan sebagai sekelompok aplikasi berbasis internet yang dibangun atas dasar ideologi dan teknologi web 2.0 yang memungkinkan penciptaan dan pertukaran user generated content. Dengan begitu, media sosial merupakan sebuah media berbasis kecanggihan teknologi yang diklasifikasikan dari berbagai bentuk seperti majalah, forum internet, weblog, blog sosial, microblogging, wiki, foto atau gambar, video peringkat dan bookmark sosial (Kaplan \& Haenlein, 2010). Lebih lanjut, media sosial memiliki karakteristik dan sifat penting media sosial diantaranya; Pertama, media sosial sebagai alat, aplikasi, platform dan media online memiliki ketergantungan pada teknologi informasi. Kedua, media sosial merupakan saluran komunikasi partisipatif dua arah yang memungkinkan terjadinya interaktif, kolaborasi dan pertukaran antar pengguna. Ketiga, media sosial bisa menghubungkan pengguna untuk membentuk sebuah komunitas virtual dengan menggunakan lintas platform, sehingga pada akhirnya dapat memengaruhi perilaku pengguna dalam kehidupan nyata (Cohen, 2011). Selain itu media sosial didefinisikan sebagai alat atau sarana komunikasi sehingga memungkinkan seseorang dapat menyiarkan, menjangkau hingga mempengaruhi orang lain secara luas (Wells, 2011).

Meski demikian, ada beberapa alasan penggunaan media sosial oleh publik diantaranya; Pertama, sebagai akses informasi. Media sosial dalam hal ini digunakan untuk mengetahui segala sumber informasi yang dapat menciptakan terbentuknya masyarakat yang melek informasi (well-informed citizenry). Kedua, sebagai askes interaksi. Dalam hal ini media sosial dapat menjadi medium yang menjanjikan potensi interaktivitas paling tinggi di antara anggotanya bila dibandingkan dengan media massa sebelumnya. Dalam konteks ini media sosial adalah media interpersonal yang memungkinkan penerima informasi terlibat dalam komunikasi interaktif dengan penyampai informasi. Ketiga, sebagai saluran partisipasi. 
Dengan kata lain, saluran partisipasi ini muncul dari keterlibatan para warga negara untuk mewujudkan kepentingan umum yang berbasis digital. Sehingga kemudian melahirkan semangat partisipatif dan menjadikan warganet menjadi warga negara yang aktif terlibat dalam berbagai kegiatan. Dalam konteks politik Indonesia partisipasi aktif ini telah melahirkan fenomena relawan politik (Arianto, 2014). Keempat, sebagai ikon desentralisasi. Dalam konteks ini peran media sosial dapat memudahkan urusan pemerintahan agar lebih mendekat ditengah masyarakat. Sehingga keterlibatan ini membuat public bisa ambil bagian dalam setiap kebijakan public dan praktik demokrasi lainnya (Nugroho \& Widodo, 2011).

Selanjutnya, perlu diketahui bahwa media sosial terdiri dari tiga bagian yakni; Pertama, infrastruktur informasi dan alat yang digunakan untuk memproduksi dan mendistribusikan konten. Kedua, konten digital yang berasal dari pesan pribadi, berita, ide, dan produk budaya lainnya. Ketiga, organisasi, perseorangan dan industri yang memang menghasilkan dan mengkonsumsi konten digital (Howard \& Malcolm R, 2012).

Media sosial berpengaruh terhadap pembentukan politik komtemporer yang demokratis. Seperti forum diskusi online yang telah memberi kebebasan untuk mengekspresikan keseluruhan pertanyaan dan emosi yang mereka miliki sekaligus memberdayakan untuk menantang praktik medis yang mengakar dengan cara ini (Loader \& Dan, 2011). Fragmentasi sosial dan penurunan loyalitas kelompok selama ini telah memunculkan era politik yang dipersonalisasi yang mana tindakan pribadi ekspersif telah menggantikan kerangka aksi kolektif dalam banyak aksi protes. Tren ini kemudian dapat dilihat dengan munculnya partisipasi politik berskala besar yang dengan cepat membentuk berbagai sasaran, mulai dari partai, kandidat, perusahaan, merek hingga organisasi transnasional (Bennett, 2012). Fenomena ini yang kemudian diambil alih oleh media sosial dengan saluran partisipatifnya. Meski demikian, ada studi yang menilai penggunaan media sosial untuk interaksi sosial tidak memiliki pengaruh langsung dalam keterlibatan politik masyarakat, tetapi lebih merupakan efek tidak langsung dari cara warga masyarakat untuk mengekspresikan diri secara politis (Gil de Zúñiga, H, et.al, 2014). Meski begitu dalam konteks bisnis, dampak penggunaan media sosial bagi perusahaan telah meningkatkan frekuensi kunjungan para pelanggan (Rishika, 2013).

\section{Drone Emprit Academic}

Drone Emprit Academic merupakan sebuah sistem yang mampu memonitor dan menganalisis media sosial dan berbagai online platform berbasis teknologi big data yang menggunakan artifial intelligence (AI) dan natural learning process (NLP), serta mampu menyajikan peta Social Media Network Analysis (SNA) tentang bagaimana fenomena sosial yang terjadi itu berasal, menyebar, siapa yang menginisiasi, dan kelompok-kelompok mana yang membicarakannya. Selanjutnya Drone Emprit Academic menggunakan API (Aplikasi Programming Interface) layanan dari Twitter untuk menangkap percakapan secara realtime melalui 
metode streaming. (Adji, Bashith, Nasith, \& Amin, 2019). Lebih lanjut, data yang disajikan dalam peta analisis jaringan sosial dapat menjelaskan terkait bagaimana fenomena sosial berasal, menyebar, sehingga mengetahui siapa yang menjadi buzzer, influencer dan klister lainnya (Fahmi, 2017).

\section{METODE}

Penelitian ini bersifat kualitatif diskriptif. Metode penelitian kualitatif yang digunakan dalam penelitian ini adalah studi kasus. Dalam konteks ini studi kasus merupakan salah satu pendekatan penelitian kualitatif yang sengaja didisain untuk menggali dan menemukan proses atau perilaku baru sebagai obyek penelitian yang belum banyak dipahami secara luas (Dobson, 1999). Obyek penelitian ini adalah penggunaan aplikasi Drone Emprit Academic dalam membaca percakapan warganet di media social selama bulan Desember 2020. Data yang dianalisis dalam penelitian ini berupa percakapan warganet mengenai topik Bank Syariah Muhammadiyah. Pada Drone Emprit Academic, teknik pengumpulan data terhadap percakapan mereka tersebut menggunakan Social Network Analysis (SNA) dari Drone Emprit Academic (DEA) Universitas Islam Indonesia ((Adji, Bashith, Nasith, \& Amin, 2019; Suharso, 2019). Sedangkan proses pelacakan dari percakapan para warganet melalui beberapa tahapan diantaranya; Pertama, menganalisis semua klaster dari percakapan warganet berdasarkan kata kunci Bank dan Muhammadiyah. Kedua, menentukan rentang waktu percakapan warganet. Ketiga, menganalisis kata kunci melalui Social Network Analysis dan kemudian di uraikan berdasarkan influencer, buzzer dan follower. Keempat, memilah percakapan berdasarkan jumlah retweet, mention, penggunaan konten dan tagar yang digunakan. Kelima, mendeteksi persentase akun bot (robot) dalam percakapan. Keenam, identifikasi para warganet berdasarkan jumlah usia para pengguna. Terakhir menentukan wilayah mana saja asal para warganet yang berpartisipasi dalam percakapan tersebut.

\section{HASIL DAN PEMBAHASAN}

\section{Aktor Warganet di Media Sosial}

Warganet adalah para pengguna berbagai platform media sosial yang secara aktif berinteraksi satu sama lain secara digital di dunia maya. Pendekatan aktor sosial memandang para pengguna media sosial sebagai makhluk sosial yang berkomunikasi secara digital dan mendasarkan prinsip-prinsip sociotechnical interaction (Prajarto, Tania, \& Purwaningtyas, 2019). Prinsip-prinsip interaksi antara aspek sosial dan teknologi tersebut meliputi jaringan tanpa batas, terjadinya perubahan secara kontinyu, simetri pada kedua aspek, serta tindakan dan struktur dalam konteks sosial dan teknologi (Sawyer \& Jarrahi, 2013). Warganet dibedakan berdasarkan klasifikasi tingkat keaktifan mereka dalam menggunakan media sosial (Arianto, 2019).

Klasifikasi tersebut membentuk beberapa istilah berdasarkan peran mereka untuk memperkuat dan menyebarluaskan pesan atau konten digital. Peran-peran yang ada dalam masyarakat digital adalah buzzer, influencer, dan follower. Di media sosial, buzzer lebih diartikan sebagai akun yang 
setiap saat bertindak menyebarluaskan, mengkampanyekan, dan mendengungkan pesan atau konten digital kepada warganet lainnya dengan tujuan mempengaruhi maupun menguatkan pesan atau konten tersebut (Arianto, 2019). Di sisi lain, influencer merupakan akun media sosial yang memiliki pengaruh sangat kuat terhadap para followersnya, sehingga akun tersebut mampu mendorong dan mempengaruhi para followers untuk bertindak sesuai yang dikehendaknya (Arianto, 2020). Sesuai karakternya, follower adalah akun media sosial yang mengikuti perilaku akun influencer dan buzzer. Para follower merupakan warganet yang tunduk sesuai keinginan influencer dan buzzer yang diikutinya.

Akun media sosial yang berperan sebagai buzzer akan bertindak: (1) membentuk dan memperkuat opini publik dalam ranah media sosial, yakni menempatkan opini tersebut pada trending topic di suatu platform media sosial; (2) membangun isu publik yang berasal dari investigasi individu maupun influencer yang memiliki gagasan sama dengan isu tersebut; dan menyebarluaskan pesan atau konten digital di sebanyak mungkin platform media sosial, sehingga pengaruhnya akan semakin kuat atas nalar para warganet. Berikut klasifikasi warganet yang akan dijelaskan dalam table 1.

Tabel 1. klasifikasi warganet

\begin{tabular}{|c|c|c|c|}
\hline & Follower & Buzzer & Influencer \\
\hline Definisi & $\begin{array}{lr}\text { Akun media } \\
\text { sosial yang } \\
\text { mengikuti } \\
\text { yang kita miliki. }\end{array}$ & $\begin{array}{l}\text { Akun media sosial yang } \\
\text { setiap saat } \\
\text { menyebarluaskan, } \\
\text { mengkampanyekan dan } \\
\text { mendengungkan suatu } \\
\text { pesan atau konten kepada } \\
\text { warganet dengan tujuan } \\
\text { memperkuat pesan atau } \\
\text { konten tersebut }\end{array}$ & $\begin{array}{l}\text { Akun media sosial yang } \\
\text { memiliki pengaruh kuat } \\
\text { terhadap para follower- } \\
\text { nya sehingga bisa } \\
\text { mendorong para } \\
\text { follower-nya bisa berbuat } \\
\text { sesuai nalar atau } \\
\text { kehendaknya. }\end{array}$ \\
\hline $\begin{array}{l}\text { Sifat } \\
\text { Akun }\end{array}$ & $\begin{array}{l}\text { Anonim dan } \\
\text { nyata (real) }\end{array}$ & Mayoritas akun anonim & $\begin{array}{l}\text { Mayoritas akun nyata } \\
\text { (real) }\end{array}$ \\
\hline $\begin{array}{l}\text { Jumlah } \\
\text { follower }\end{array}$ & $1-500$ & $1-2000$ & $>10.000$ \\
\hline
\end{tabular}

Sumber : (Arianto, 2020).

Dari tabel 1, menjelaskan mengenai peran dan fungsi beberapa aktor warganet. Dimulai dari follower berfungsi sebagai penerima akhir pesan dari buzzer dan influencer. Selain itu peran lainya yaitu ikut menyebarluaskan berbagai pesan dari buzzer dan influencer. Lebih lanjut, aktor lainnya yaitu buzzer berfungsi diantaranya; Pertama, untuk membentuk opini publik dalam ranah media sosial yakni dengan menempati trending topik Twitter. Kedua, kut membangun isu publik yang berasal 
dari investigasi individual ataupun berasal dari influencer yang seide dengan isu tersebut. Memperkuat pesan dari influencer melalui repost, retweet dan re-share hingga pesan tersebut viral di semua media sosial.

Meski demikian hingga saat ini dikenal buzzer bisnis dan politik. Untuk buzzer bisnis fokus pada (1) membangun citra positif (supporting), (2) mengklarifikasi citra (defensif). Sedangkan buzzer politik fokus pada (1) membangun citra positif (supporting), (2) mengklarifikasi citra (defensif) (3) menyerang dan merusak citra pesaing (offensive). Selain itu aktor warganet lainnya adalah influencer yaitu (1) Membangun ide awal bagi pembentukan opini publik yang diteruskan oleh buzzer dan follower dengan trending topik. (2) Membangun isu dan opini melalui proses investigasi jurnalisme warga. Tujuannya untuk membantu para follower memahami isu yang lagi trend. (3) Menciptakan berbagai tagar yang biasaya trending topik di Twitter. (4) Bergerak secara individual dan lebih berpegang teguh pada prinsip atau pendapat pribadi sesuai isu yang lagi trending. Terakhir peran follower. Dalam konteks ini para follower berperan sebagai penerima akhir pesan dari buzzer dan influencer. Selanjutnya juga berperan menyebarluaskan pesan dari buzzer dan influencer. Dalam hal ini para follower selalu berusaha tampil mengikuti kehendak akun media sosial yang diikutinya. Sehingga para follower ini akan ikut memperkuat pesan yang disampaikan, baik oleh buzzer maupun influencer dengan cara me-retweet, memberikan komentar, dan menyukai pesan tersebut.

\section{Aplikasi Drone Emprit Academic}

Aplikasi Drone Emprit Academic (DEA) dapat menganalisis jejaring sosial secara spesifik berupa percakapan di Twitter dan Instagram secara semirealtime dan detail. Percakapan real time dapat dibaca saat analisis ini dilakukan dan aplikasi dapat membaca percakapan sebelumnya dengan rentang waktu tidak lebih dari sepekan (DEA UII, 2019). Berdasarkan identifikasi tersebut, penelitian ini akan mengelaborasi kembali peran aplikasi Drone Emprit Academic (DEA) Universitas Islam Indonesia dalam membaca tren percakapan yang berkembang di warganet secara kekinian dengan kata kunci Bank dan Muhammadiyah. Sedangkan media sosial yang diteliti terbatas hanya pada percakapan warganet di Twitter.

Data besar yang disediakan oleh Drone Emprit Academic mampu menemukan fenomena sosial. Hasil penelitian ini menunjukan bahwa Drone Emprit Akademic adalah sistem data besar yang melakukan analisis jejaring sosial spesifik percakapan di Twitter semi-realtime dan detail. Formulir yang ditampilkan adalah dalam bentuk persentase tren, retweet hubungan, menyebutkan tren grafik, sebagian besar status retweet, tren percakapan. Data yang dihasilkan dapat membantu membaca informasi tentang fenomena sosial sehingga dapat mendukung literasi kritis yang telah dipublikasikan sebagian di media online dan offline. Berdasarkan identifikasi tersebut, penelitian ini akan mengelaborasi kembali peran aplikasi Drone Emprit Academic (DEA) Universitas Islam Indonesia dalam membaca tren yang 
berkembang di warganet secara kekinian. Penelitian ini akan lebih menekankan pada percakapan warganet di media sosial Twitter. Implikasi dalam penelitian ini seputar pemanfaatan aplikasi Drone Emprit Academic (DEA) dalam membaca percakapan dan isu yang berkembang di warganet secara kekinian.

Lebih lanjut aplikasi Drone Emprit Academic akan melakukan analisis percakapan melalui beberapa tahapan yaitu, (1) Menganalisis semua klaster dari percakapan warganet berdasarkan kata kunci Bank dan Muhammadiyah. (2) Menentukan rentang waktu percakapan warganet. (3) Menganalisis kata kunci melalui Social Network Analysis dan kemudian di uraikan berdasarkan influencer, buzzer dan follower. (4) Memilah percakapan berdasarkan jumlah retweet, mention, penggunaan konten dan tagar. (5) Mendeteksi persentase akun bot (robot) dalam percakapan. (6) Mengidentifikasi para warganet berdasarkan jumlah usia para pengguna. (7) Menentukan wilayah para warganet yang berpartisipasi.

Berikut ini akan dijelaskan penerapan aplikasi Drone Emprit Academic dalam menganalisis percakapan dengan kata kunci "Bank" dan "Muhammadiyah".

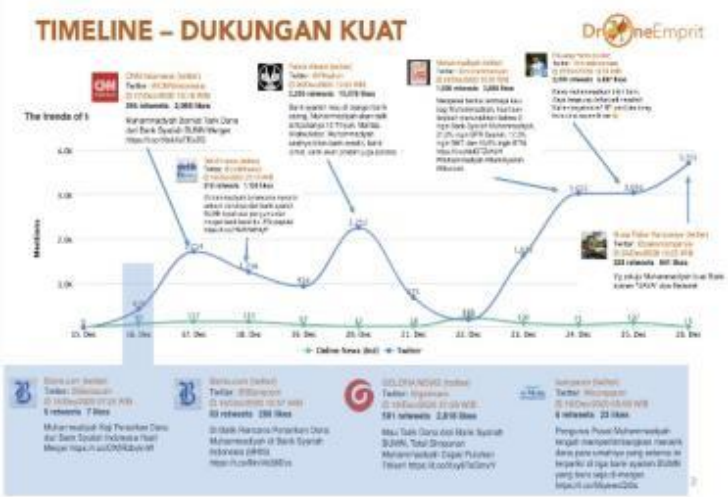

Gambar 1. Timeline Dukungan Kuat
Percakapan mengenai Bank Syariah Muhammadiyah diketahui sejak tanggal 16 November 2020. Drone Emprit Academic menggunakan keyword "Muhammadiyah" dengan filter Bank yang kemudian menghasilkan beberapa temuan.

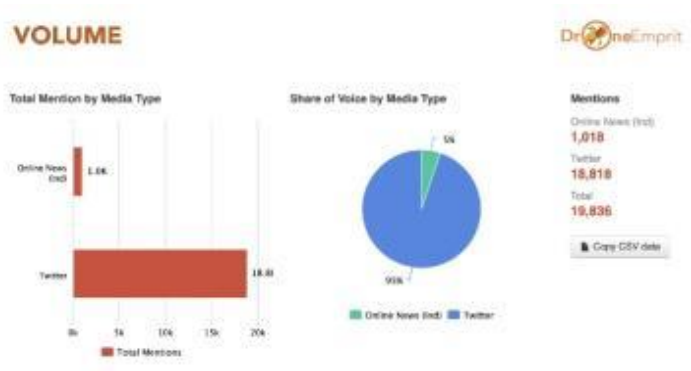

Gambar 2. Volume percakapan warganet

Drone Emprit Academic menemukan percakapan sebanyak 1000 mention pada tanggal 15-26 Desember 2020 di Twitter dengan topik Bank dan Muhammadiyah. Temuan ini mengonfirmasi bahwa warganet sangat antusias memberikan komentar pada percakapan dengan tema tersebut.

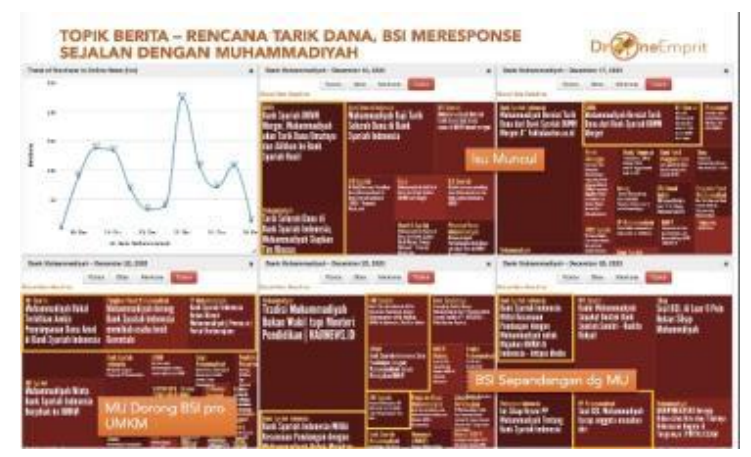

Gambar 3. Volume percakapan warganet

Percakapan warganet dengan tema Bank ini viral dikarenakan pada awalnya banyak pemberitaan yang 
menyebutkan bahwa Muhammadiyah akan menarik dana umatnya. Hal itu yang membuat PP Muhammdiyah membuat pernyatan pers yang kemudian mendorong BSI untuk lebih memihak UMKM. Pernyataan ini kemudian disambut oleh warganet untuk kemudian memberikan pastisipasi melalui berbagai macam komentar.

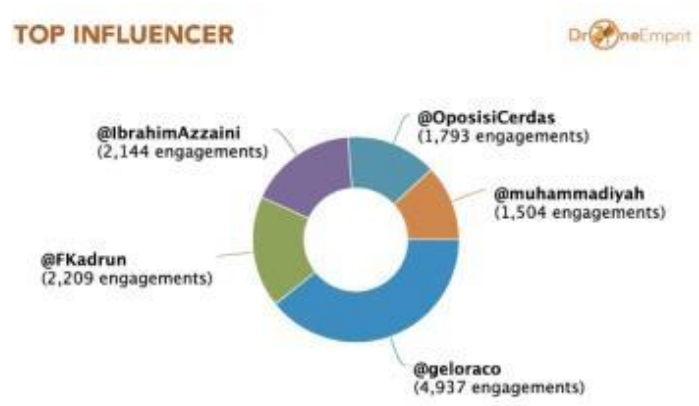

Gambar 4. Top akun influencer

Dari percakapan ini hasil temuan Drone Emprit Academic menyatakan yang menjadi influencer atau akun berpengaruh adalah akun @geloraco @FKadrun@@IbrahimAzzaini @OposisiCerdas@Muhammadiyah. Dengan kata lain, akun inilah yang menjadi pematik untuk bisa menarik partisipasi warganet memberikan komentar dengan tema Bank dan Muhammadiyah.

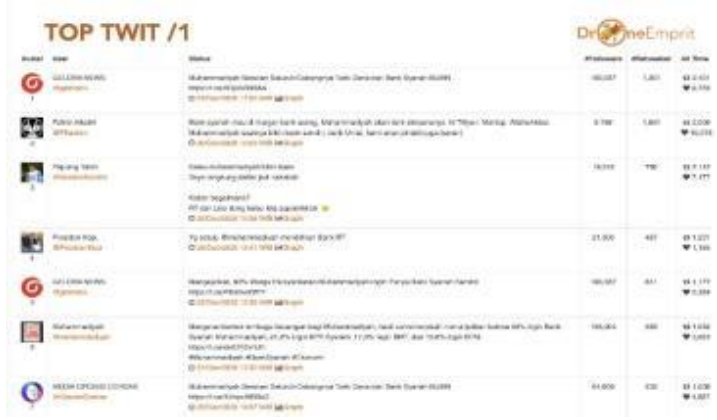

Gambar 5. Top narasi dari warganet
Analisis Drone Emprit Academic menyatakan bahwa banyak warganet yang memberikan masukan agar Muhammadiyah memiliki bank sendiri. Selain itu adapula masukan dari warganet agar Muhammadiyah menarik dan memindahkan dananya. Selain itu top narasi lainnya adalah polling internal agar 90 persen warga Muhammadiyah ingin memiliki Bank Syariah tersendiri. Dengan kata lain, topik Bank dan Muhammdiyah telah menarik partisipasi uwarganet untuk memberikan masukan yang konstruktif atas informasi ini.

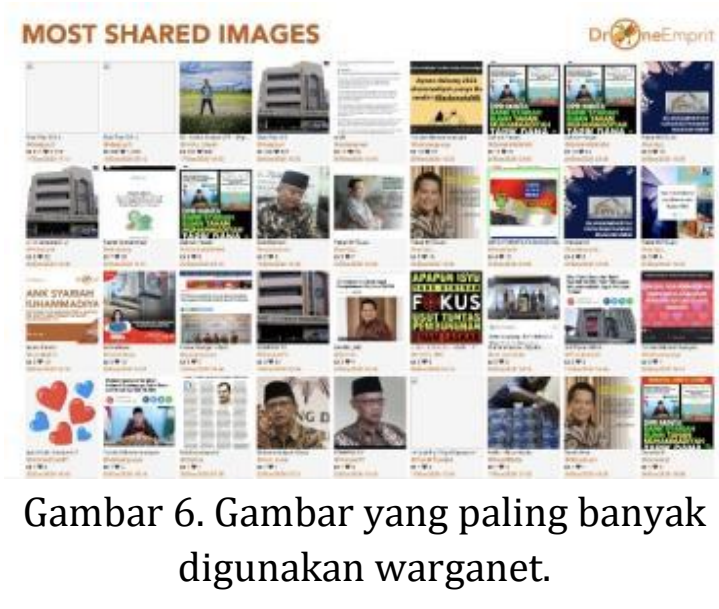

Percakapan warganet mengenai topik Bank dan Muhammdiyah juga menggunakan beberapa konten. Berbagai konten ditemukan paling banyak menarik atensi warganet dalam percakapan ini. Dengan demikian, konten dalam konteks warganet juga merupakan hal yang utama. Dari gambar yang diunggah oleh warganet ternyata paling banyak ditemukan adalah berita mengenai Muhammadiyah akan menarik dana dari BSI BUMN dan BSI Muhammdiyah sudah capai kesepakatan untuk memajukan UMKM. 


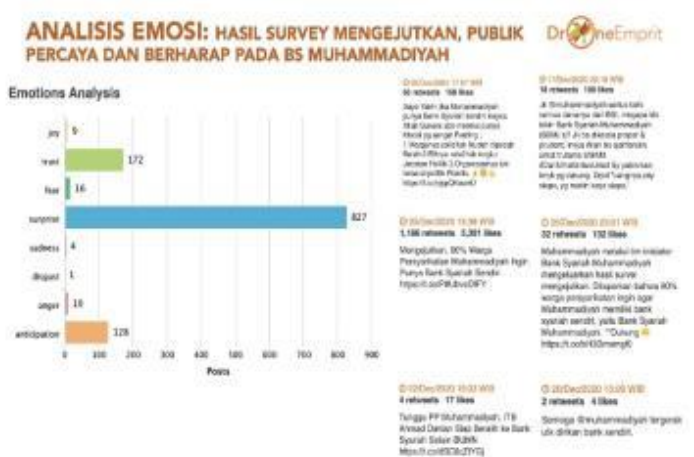

Gambar 7. Analisis emosi para warganet

Dari analisis Drone Emprit Academic ditemukan analisis emosi para warganet dengan yang paling dominan adalah surprise atau terkejut atas hasil survei internal warga Muhammadiyah yang menjelaskan bahwa 90 persen mendukung untuk memiliki Bank Syariah sendiri. Kemudian analisis emosi juga tergambar dari "trust" atau percaya pada Bank Syariah Muhammadiyah untuk bisa membantu UMKM. Terakhir adalah harapan (anticipation) agar keinginan Bank Syariah Muhammdiyah benar terwujud.

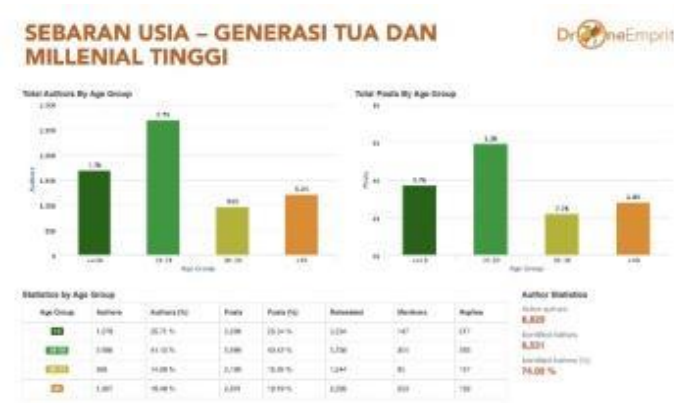

Gambar 8. Sebaran usia warganet

Aplikasi Drone Emprit Academic juga memiliki cara untuk menganalisis sebaran usia para pengguna warganet. Dari 8800 ribu pengguna aktif, ternyata ditemukan bahwa generasi tua berusia 40 tahun lebih sangat tinggi terlibat dalam percakapan tema ini, atau sebesar 74 persen. Sisanya diikuti okeh generasi milenial dibawah 40 tahun.

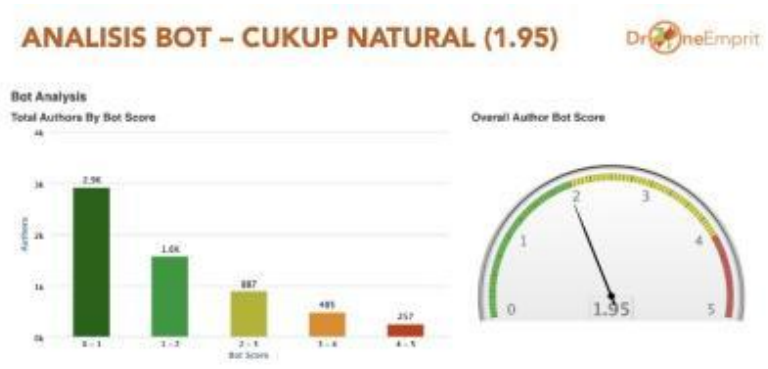

Gambar 9. Sebaran usia warganet

Aplikasi Drone Emprit Academic memberikan analisis untuk mengetahui sebaran akun bot. Pada percakapan ini ditemukan bahwa akun bot hanya berkisat rata-rata 1,95 atau bertanda hijau. Dengan demikian, percakapan dengan topik Bank dan Muhammadiyah sangat natural berasal dari warganet. Dengan kata lain percakapan ini bukan karena rekayasa akun robot.
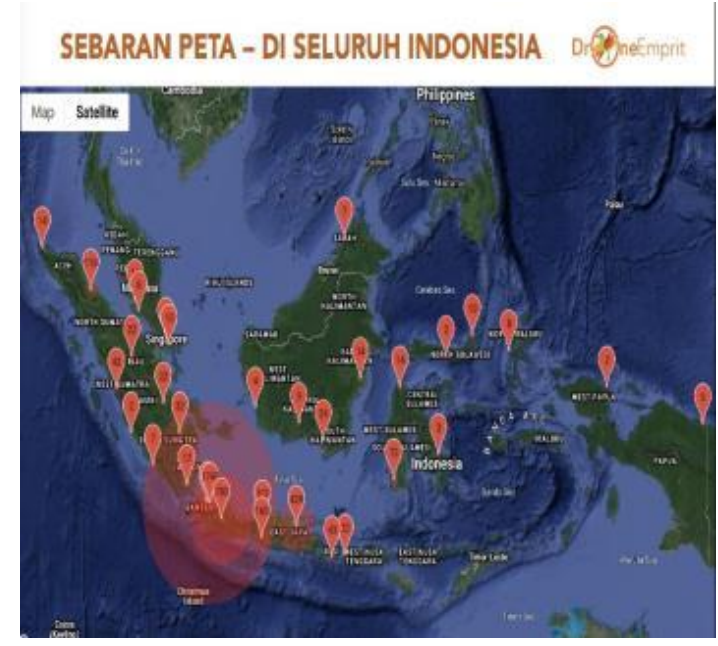

Gambar 10. Sebaran usia warganet

Percakapan mengenai topik Bank dan Muhammadiyah ini masih didominasi oleh warganet yanbg berasal dari Jakarta, Bandung, Surabaya dan Jogja. Sedangkan daerah lain tidak begitu banyak meski persebarannya cukup merata. Hal ini menunjukan bahwa 
pengguna Twitter sangat merata di Indonesia.

Beberapa tahapan yang dilalui dari penggunaan aplikasi Drone Emprit Academic telah mengonfirmasi bahwa media sosial bisa digunakan dalam menganalisis opini public yang sedang berkembang saat ini. Opini publik ini bisa menjadi katalisator warganet dalam membaca isu apa yang sedang saat ini, Meski percakapan warganet memiliki karakter hit dan run. Akan tetapi, percakapan ini sudah termasuk sebagai bentuk partisipasi digital para warganet yang notabener dikategori kelas menengah. Meski demikian, partisipasi digital yang muncul ini juga banyak dibentuk oleh berbagai factor seperti sumber daya manusia, jejaring sosial, kelembagaan digital hingga akses internet (Vicente \& Novo, 2014).

\section{E. SIMPULAN DAN SARAN}

Peran strategis media sosial di era digitalisasi semakin memiliki andil yang besar terutama dalam pembentukan opini publik. Media sosial dapat menjadi saluran partisipasi dari masyarakat dunia. Bahkan lebih dari itu media sosial telah menjadi sumber informasi menarik dari media mainstream di Indonesia saat ini. Banyak informasi terbaru yang viral dan banyak diperbincangkan oleh publik yang berasal dari media sosial. Inilah yang membuat media sosial kian menjadi inspirasi dalam membentuk dan membangun opini public. Tidak heran bila banyak pihak berupaya membuat opini publik yang didahului dari media sosial hingga kemudian membentuk menjadi opini secara global. Meski demikian ada pula opini pubik yang sengaja dibuat atau dikenal unorganik. Serta ada pula opini publik yang memang tumbuh dari persoalan riil masyarakat yang kemudian disebut organik. Lebih lanjut, dalam hal ini peran aktor warganet sangat menentukan agar opini publik dapat terbangun secara organik. Meski begitu, ada beragam upaya dilakukan oleh pihak tertentu agak opini publik seolah tumbuh secara organik. Percakapan dari media sosial ini tentu menjadi sebuah keniscayaan yang harus dimanfaatkan dalam upaya membaca tren kekinian. Oleh sebab itu diperlukan aplikasi untuk membaca tren yang banyak dibicarakan oleh warganet. Dalam penelitian ini aplikasi Drone Emprit Academic dapat menjadi salah satu alternatif untuk membaca dan menganalisis opini publik yang tengah berkembang saat ini. Melalui aplikasi ini diketahui aktor yang telah berpartisipasi secara digital memberikan komentar dan masukan atas berbagai permasalahan riil rakyat. Aplikasi ini juga dapat menganalisis akun-akun inisiator yang kemudian dikategorikan sebagai buzzer, influencer, dan follower untuk setiap wilayah sesuai kelompok generasi dan usia yang diteliti. Aplikasi Drone Emprit Academic telah membuktikan bahwa, percakapan yang dihasilkan dari media sosial bisa menjadi alternatif dalam membaca opini publik. Artinya percakapan ini sudah bisa dikatakan sebagai opini publik yang kekinian. Dalam penelitian ini analisis Drone Emprit Academic menemukan bahwa mayoritas warganet telah memberikan masukan agar Muhammadiyah memiliki Bank Syariah sendiri dan juga harapan agar Muhammadiyah bisa sfokus dalam 
membantu UMKM. Selain itu analisis emosi juga ditemukan yang mengambarkan keinginan warganet agar Muhammadiyah menarik dan memindahkan dananya dari Bank Syariah Indonesia (BSI). Dari analisis dapat disimpulkan bahwa media sosial telah berkontribusi mendorong warganet untuk ikut terlibat aktif dalam membicarakan topik Bank dan Muhammadiyah. Dengan demikian para warganet ini telah berperan menjadi aktor dalam pembentukan opini publik dalam langgam demokrasi digital di Indonesia.

\section{DAFTAR PUSTAKA}

Arianto. B. (2019). Kontestasi Relawan Teman Ahok dalam Pemilihan Kepala Daerah DKI Jakarta 2017. Journal of Social Politics and Governance. 1, (1). 40-55.

. (2019b). Kontestasi Buzzer Politik dalam Mengawal APBD DKI Jakarta. Jurnal Polinter Prodi Ilmu Politik FISIP UTA'45 Jakarta. 5 (1) 54-76.

. (2015). Kampanye Kreatif Dalam Kontestasi Presidensial 2014. Jurnal Ilmu Sosial dan Ilmu Politik UGM. No 1, 19: 16-39.

. (2014). Fenomena Relawan Politik dalam Kontestasi Presidensial 2014. Jurnal Ilmu Sosial dan Ilmu Politik UGM. 18, No 2, November (146-162)

.(2020). Salah Kaprah Ihwal Buzzer : Analisis Percakapan Warganet di Media Sosial. Jurnal Ilmiah Ilmu Pemerintahan (JIIP) Undip, 5 (1), 1-20.

.(2020). Peran Buzzer Media Sosial dalam Memperkuat Ekosistem Pemasaran Digital. Jurnal Optimum $U A D, 10$ (1). Maret, 51-65
Adji, W. S., Bashith, A., Nasith, A., \& Amin, S. (2019). Identification of Social Symptoms Using the Drone Emprit Academic as a Support for Statistical Literacy. Abjadia: International Journal of Education, 04(02), 97-106. https://doi.org/10.18860/abj.v4i2 .8412

Bennett, W. L. (2012). The personalization of politics: Political identity, social media, and changing patterns of participation. The annals of the American academy of political and social science, 644(1), 20-39.

Cohen, H. (2011). 30 social media definitions. Posted by Heidi Cohen on May 9, 2011 in actionable marketingSocial media, 101, (Available from: http://heidicohen.com/ socialmedia-definition/. Accessed on 25 February 2013)

DEA UII (2019). Drone Emprit Academic Open Data: Portal Data Analisis Media Sosial. Universitas Islam Indonesia Yogyakarta. https://dea.uii.ac.id/

Dobson, P. J. (1999). Approaches to Theory Use In Interpretive Case Studies - a Critical Realist Perspective. In 10th Australasian Conference on Information Systems (pp. 259-270). Churchlands: Edith Cowan University.

Effing, R., Van Hillegersberg, J., \& Huibers, T. (2011). Social media and political participation: are Facebook, Twitter and YouTube democratizing our political systems?. In International conference on electronic participation (pp. 25-35). Springer, Berlin, Heidelberg.

Fahmi, I. (2017). Drone Emprit: Konsep dan teknologi, IT Cam on Big data and Data Mining, Jakarta. 
(2019). Data Social Network Analysis Drone Emprit Academic Universitas Islam Indonesia. Yogyakarta.

(2019). Buzzer Politik dan Demokrasi. Yogyakarta.

Gil de Zúñiga, et al (2014). Social media, political expression, and political participation: Panel analysis of lagged and concurrent relationships. Journal of communication, 64(4), 612-634.

Howard, Philip N., and Malcolm R. Parks. "Social media and political change: Capacity, constraint, and consequence." (2012): 359-362.

Kaplan, A \& Michael Haenlein (2010). Users of the world, unite! The challenges and opportunities of Social Media. Business Horizons, 53 (1), 59-68.

Lewis, S., Pea, R., \& Rosen, J. (2010). Beyond participation to cocreation of meaning: mobile social media in generative learning communities. Social Science Information, 49(3), 351-369.

Loader, Brian D., and Dan Mercea.

"Networking democracy? Social media innovations and participatory politics." Information, Communication \& Society 14 , no. 6 (2011): 757-769.

McGregor, S. C. (2019). Social media as public opinion: How journalists use social media to represent public opinion. Journalism, 20(8), 10701086.

Rishika, R., Kumar, A., Janakiraman, R., \& Bezawada, R. (2013). The effect of customers' social media participation on customer visit frequency and profitability: an empirical investigation. Information systems research, 24(1), 108-127.
Sociotechnical approaches to the study of information system. Dalam A. Tucker \& H. Topi (eds). CRC Handbook of Computing. London: Chapman and Hall, Inc.

Suharso, P. (2019). Pemanfaatan Drone Emprit dalam Melihat Trend Perkembangan Bacaan Digital melalui Akun Twitter. Anuva, 3(4), 333-346.

Tirto.id. (2017). Mengenang friendster dan media sosial jadul yang lain. (Online). https://tirto.id/mengenangfriendster-dan-media-sosial-jadulyang-lain-csMe Diakses 10 Januari 2020

Vicente, M. R., \& Novo, A. (2014). An empirical analysis of eparticipation. The role of social networks and e-government over citizens' online engagement. Government Information Quarterly, 31(3), 379387.

Watie, E. D. S. (2016). Komunikasi dan media sosial (communications and social media). Jurnal The Messenger, 3(2), 69-74.

Wells, W. H. (2011). Social media and social networking: What's the difference? Available online. http://www.williamhwells.com/2 011/06/18/social-media-andsocialnetworking-whats-thedifference/ (Accessed on 9 December 2013)

Sawyer, S., \& Jarrahi, M. H. (2013). 